\title{
Influence of Ecoclimatic and Ecopedological Conditions on Quality of White Wine Grape Varieties from North-West of Romania
}

\author{
Florin-Dumitru BORA ${ }^{1^{*}}$, Tiberia Ioana POP'), Claudiu-Ioan BUNEA ${ }^{1)}$, \\ Delia-Elena URCAN ${ }^{1)}$, Anca BABEŞ ${ }^{1)}$, Leonard Mihaly-COZMUTA ${ }^{2)}$, \\ Anca Mihaly-COZMUTA ${ }^{2)}$, Nastasia $\mathrm{POP}^{1 *}$ \\ 1) Faculty of Horticulture, University of Agricultural Sciences and Veterinary Medicine Cluj-Napoca, \\ Romania. \\ 2) Technical University of Cluj-Napoca, Baia-Mare Research Center, Romania. \\ ${ }^{*}$ Coresponding author, e-mail: nastpop@yahoo.com, boraflorindumitru@gmail.com.
}

Bulletin UASVM Horticulture 71(2) / 2014

Print ISSN 1843-5254, Electronic ISSN 1843-5394

DOI:10.15835/buasvmcn-hort:10545

\begin{abstract}
Viticulture is one of the cultures occupying large proportions of the cultivated area on the Globe. It is practiced, in particular, to produce table grapes, juice and other derivatives, and especially (about $70 \%$ of the total) to obtain different categories of quality wine and wine-based beverages. Wine can be produced everywhere, as long as the grapes ripen, but not all conditions for ripening the grapes are favorable for the production of quality wines (Teodorescu et al., 1987). If the area where vine is grown is large, the one objective is to evaluate the ecoclimatic and ecopedological conditions of three culture areas (Baia Mare (BM), Şimleul Silvaniei (SS) and Turulung Vii (TUR)) in north-western Romania and their influence on the quality of the varieties: 'Fetească albă', 'Fetească regală', 'Riesling italian'. The genetic soil types from these locations are: aluvosoil in Baia Mare, luvosoil in Şimleul Silvaniei and preluvosoil in Turulung Vii. 2013 was a year with higher average temperatures than the annual average in Baia Mare and Turulung Vii, but lower in Şimleul Silvaniei, but the precipitations were lower in the same areas, compared to the multiannual average. The higher amount of sugar was accumulated in 'Fetească albă' in Şimleul Silvaniei and the lowest in 'Fetească regală' in Baia Mare, the acidity falling between a normal interval for wine varieties.
\end{abstract}

Keywords: ecoclimatic and ecopedological conditions, grapes varieties for white wine, quality (sugar, acidity, pH).

\section{INTRODUCTION}

Vineyards need a specific climate, well defined and constantly monitored, any changes may have a negative effect on them and the wine (Schaller, 2011).

It is estimated that globally vines have around 10000-12000 varieties. This plurality of varieties shows directly that vine is a plant with a high genetic variation, and it is able to adapt to the different environmental conditions. Because of these qualities, the vine is successfully cultivated in many countries, its cultivation is considered one of the most (Dobrei et al., 2009).

The favorable ecoclimatic conditions for vine culture are divided into two categories: the compulsory and natural critical conditions. The compulsory conditions are important and directly promote growth and fructification of vines, some of these factors are solar radiation, temperature, light, and humidity. The natural critical conditions affect the growth and fructification of vines, resulting in decreased quantitative and qualitative production (Pop, 2010). The quality of the grapes is also directly influenced by variety, ecoclimatic conditions of the applied agrotechnical works and zoning (Bunea et al, 2013). Most authors argue that for determining the quality of a wine, the following must be taken into account: biochemical characteristics of must, sugar content, acidity and pH (Bunea et al., 2010). 
The research shows the ecopedological ecoclimatic conditions in Transylvania influence directly vines, especially the cultivation of vines for producing quality white wines (Călugăr et al., 2009).

The effect of ecoclimatic conditions in viticulture is largely documented (Winkler et al., 1974; Gladstones, 1992), and the effect of ecopedological conditions in viticulture was documented (Seguin 1986).

This paper is proposing to characterize the influence of ecoclimatic and ecopedological conditions on wine grape quality in three areas from North-West of Romania (Baia Mare, Șimleul Silvaniei, Turulung Vii) and the analysis of quality indices (sugar, acid an $\mathrm{pH}$ ) at three white wine grape varieties.

\section{MATERIALS AND METHODS.}

The wine grape varieties grown in the three areas studied (Baia Mare, Șimleul Silvaniei and Turulung Vii) are: 'Fetească albă', 'Fetească regală', 'Riesling italian', grafted on Berlandieri x Riparia Kobber 5 BB rootstock. The genetic soil types for each location were taken from research carried out by other authors (Szentesi, 2002; Blaga, 2005). The samples of grapes were harvested in 2013. About $5 \mathrm{~kg}$ of grapes per variety were harvested, from different vines, grapes from the lower, middle and top third of each vine stock and grapes exposed to sun and shade, so a homogenization of the samples was made. Grape harvesting was done using disposable rubber gloves. After sampling, they were placed in sealable plastic bags, were numbered and shipped as soon as possible to the laboratory where performed the analyzes. The samples were analyzed in the Laboratory of Oenology of USAMV Cluj-Napoca, for each sample, three repeats were used. The determination of sugar in must samples was performed using the hand refractometer Zi du Bompas F-49120 (Alla France) with an accuracy of 0.02 . The principle was to determine the percentage of dry matter in the must, then the value was corrected according to the temperature and the sugar content was determined using the formula:

$$
\mathrm{g}_{\text {sugar }} / \mathrm{L}_{\text {must }}=\left(\mathrm{N}^{*} \times 4,25 / 4-2.5\right) \times 10
$$

Where $\mathrm{N}=$ dry matter, 4.25 ratio between the density and refractive index and 2.5 must average content of organic substances other than grape sugars.

To determine the total acidity of the must samples, titration was used in the presence of phenolphthalein. The principle of the method consists in determining the must acids with an alkaline solution of sodium hydroxide $(\mathrm{NaOH})$, based on the constant that a milliliter of $\mathrm{NaOH}$ $0.1 \mathrm{~N}$ can neutralize $0.0049 \mathrm{~g}$ sulfuric acid. The total acidity is expressed in $\mathrm{g} / \mathrm{L} \mathrm{H}_{2} \mathrm{SO}_{4}$ (sulfuric acid), and the results were obtained with the following formula:

Total acidity g/L $\mathrm{H}_{2} \mathrm{SO}_{4}=\mathrm{V}^{*} \times \mathrm{F}^{*} \times 0.0049 \times$ $1000 / 10=0.49 \times \mathrm{V} \times \mathrm{F}$

Where $\mathrm{V}=\mathrm{mL} \mathrm{NaOH}$ used for titration; $\mathrm{F}=$ factor of $\mathrm{NaOH} ; 1000=$ the conversion factor; $10=$ the amount of must analyzed in $\mathrm{mL}$.

The pH was measured with the InoLab PH 720 WTW pH-meter, with an accuracy of 0.001.

Statistical analyses were performed using the statistical software package SPSS (version 18.0; SPSS Inc., Chicago, IL, USA), bloc vine. The data were expressed as mean \pm standard deviation (SD) of three replications for each sample analyzed. In order to determine the significance differences among values, analysis of variance (ANOVA) and DUNCAN Multiple rage Tests (MRT) were performed. Significance of difference was defined at the $5 \%$ level $(\mathrm{p}<0.05)$.

\section{RESULTS AND DISCUSIONS}

\section{Type of soil in the areas}

The soil type characteristic for Baia Mare area is aluvosoil (AS), from Protisoils class (PRO) (Blaga et al., 2005). The research conducted by Damian et al., (2008) highlights that aluvosoils occupy a large area in this area, especially along Săsar and Firiza rivers, the location where the research was conducted.

Soil contains $2-5 \%$ humus, is well supplied with nutrients, but responds very well to fertilization, and so is well suited to viticulture. The soil has a different texture from coarser to fine, most variations may occur vertically, and it is structured weak or medium. Horizon $\mathrm{C}$ appears once the depth of $50 \mathrm{~cm}$, which is, in fact, the parent material, consisting of alluvial material.

Luvosol (LV) from Class Luvisols (LUV) is the type of soil characteristic to area Şimleul Silvaniei 
(Blaga et al., 2005). Luvisols are found in all areas of the hills and plateaus, in complex with preluvisols, planosols, which occupies the depressionary lands or flat lands with poor drainage. The soil content on humus is low, $2-2.5 \%$, with a reaction moderately acidic ( $\mathrm{pH} 5.0$ to 5.8). The soil has a biologically active weak, nitrification is slow, the texture is clay-loam to loamy and the structure is from granular to flat structure, fine porous. After the depth of $140 \mathrm{~cm}$ appear gray-purple spots of stagnogleyzation.

The type of soil characteristic to area Turulung Vii is Preluvosoil (EL) from class Luvisols (LUV). These soils are found in all areas of hills and plateaus in complex with luvisols occupying a large area (5.4 million ha). Significant areas are found in: Transylvanian Plateau, West Piedmonts, Getic Plateau, Northern Drobeta and in Carpathian area (Blaga et al., 2005).

The soil is characterized by a pH of 5.3 to 5.8 , a content of $1.3-3.5 \%$ humus, $20-35$ ppm mobile phosphor, $130-220$ ppm mobile potassium, and to nitrogen the index is $1.0-2.5$. The soil responds well to lime amendments to improve the acidity and also to ameliorative fertilization for increase the pool of phosphorus in the soil (Szentesi, 2002). Texture is clay-loam, granular structure, wellformed, and after 110-140 cm depth of horizon, structure is prismatic. After the depth of $140 \mathrm{~cm}$ allow waterborne debris of calcium carbonate.

The genetic types of soils from the three sites are part of the favorable soils for vines, especially the grape varieties for high quality wine.

\section{Analysis of the main climate data}

The climatic data during the period 20042012 for Baia Mare shows there is an annual average temperature of $8,6^{\circ} \mathrm{C}$ (Tab. 1). The highest temperature for the same period was $35.8^{\circ} \mathrm{C}$, recorded in August, and the absolute minimum was $-21.7^{\circ} \mathrm{C}$ recorded in February. Also, the 10year monthly climate data reveal that during the growing season, the warmest month is July with an average temperature of $19.3^{\circ} \mathrm{C}$ and the coldest month was March with $3.0^{\circ} \mathrm{C}$. The lowest average temperature was recorded in January and was $-2.4^{\circ} \mathrm{C}$

It may also be observed that the annual average temperature in Şimleul Silvaniei during 20042012 is $12.2^{\circ} \mathrm{C}$ and is the highest temperature compared to the other two areas studied. The maximum temperature for the same period was $39.7^{\circ} \mathrm{C}$ in August and the absolute minimum was $-23.2^{\circ} \mathrm{C}$ in December.

The climatic data during 2004-2012 for Turulung Vii highlight a multianual temperature of $10.3^{\circ} \mathrm{C}$ (Tab. 1). The maximum temperature for the same period was $39.3^{\circ} \mathrm{C}$ in August and the absolute minimum of $-27.7^{\circ} \mathrm{C}$ recorded in January. Based on the multianual temperatures of the three areas studied, we can say that Şimleul Silvaniei area has the highest temperature.

Regarding the temperature, it can be observed that the vine requires this fundamental factor throughout the year in the studied areas. The hottest months proved to be July and August in all studied areas.

Tab.1. Absolute maximum, absolute minimum and average temperature of the air during 2004-2012 for the three areas of grape provenience

\begin{tabular}{|c|c|c|c|c|c|c|c|c|c|c|c|c|c|c|}
\hline & \multirow[b]{2}{*}{ Area } & \multicolumn{12}{|c|}{ Months } & \multirow{2}{*}{$\begin{array}{c}\text { Max } \\
\text { Min } \\
\text { Average }\end{array}$} \\
\hline & & I & II & III & IV & V & VI & VII & VIII & IX & $\mathrm{X}$ & XI & XII & \\
\hline \multirow{3}{*}{$\sum_{\infty}^{*}$} & Max & 15.4 & 16.7 & 20.1 & 28.4 & 30.0 & 31.5 & 35.2 & 35.8 & 31.5 & 28.4 & 21.6 & 15.7 & 35.8 \\
\hline & Min & -19.0 & -21.7 & -16.3 & -1.3 & -0.9 & 4.1 & 6.9 & 4.4 & 0.5 & -6.6 & -12.0 & -13.7 & -21.7 \\
\hline & Average & -2.4 & -1.7 & 3.0 & 9.7 & 14.1 & 17.4 & 19.3 & 18.7 & 14.1 & 7.6 & 4.2 & -0.4 & 8.6 \\
\hline \multirow{3}{*}{$\begin{array}{l}\stackrel{*}{*} \\
\tilde{\omega}\end{array}$} & Max & 16.1 & 18.3 & 21.0 & 31.8 & 33.4 & 34.6 & 38.9 & 39.7 & 36.2 & 32.4 & 24.7 & 17.2 & 39.7 \\
\hline & Min & -20.7 & -17.0 & -10.9 & -6.7 & 1.5 & 6.2 & 7.9 & 7.0 & 4.3 & -1.2 & -11.3 & -23.2 & -23.2 \\
\hline & Average & -0.3 & 1.9 & 7.1 & 13.8 & 16.0 & 21.8 & 24.1 & 25.9 & 18.3 & 11.0 & 6.0 & 1.1 & 12.2 \\
\hline \multirow{3}{*}{$\stackrel{\stackrel{*}{*}}{\stackrel{*}{*}} \underset{\Xi}{\Xi}$} & Max & 16.2 & 17.4 & 22.9 & 30.8 & 32.7 & 34.3 & 39.2 & 39.3 & 34.9 & 30.8 & 22.9 & 15.9 & 39.3 \\
\hline & Min & -27.7 & -26.9 & -11.8 & -4.4 & -2.4 & 5.6 & 7.8 & 4.8 & 0.0 & -8.6 & -11.1 & -17.6 & -27.7 \\
\hline & Average & -1.3 & -1.0 & 4.8 & 11.5 & 16.3 & 20.0 & 21.9 & 20.8 & 15.4 & 9.6 & 5.0 & 0.9 & 10.3 \\
\hline
\end{tabular}

*Baia Mare; ${ }^{* *}$ Şimleul Silvaniei; ${ }^{* * *}$ Turulung Vii 
In 2013, Baia Mare had an average annual temperature of $9.4^{\circ} \mathrm{C}$, the absolute maximum of $35.6^{\circ} \mathrm{C}$ in August and an absolute minimum of $-13.2^{\circ} \mathrm{C}$ in January (Tab. 2). Şimleul Silvaniei had, for the same period of time, the average recorded was $11.0^{\circ} \mathrm{C}$, an absolute maximum of $37.2^{\circ} \mathrm{C}$ in August and an absolute minimum of $-12.7^{\circ} \mathrm{C}$ recorded in December. The average annual temperature in Turulung Vii was $11.2^{\circ} \mathrm{C}$, the absolute maximum was $38.1^{\circ} \mathrm{C}$ in August and the absolute minimum $-10.1^{\circ} \mathrm{C}$ in January. An increase of the average annual temperature can be observed in Baia Mare and Turulung Vii, but slightly lower in Şimleul Silvaniei, probably because the city lies at the base of Magura hill and on the river Crasna, which brings cold currents of air.
As an indicator of the vocation of a vineyard, but also to establish the direction of production, the amount of temperature degrees and the thermal balance have an absolute importance (Pop, 2010).

The length of the vegetation period is within the normal cultivation limits of vines, over 170 days. In 2013, the limit was exceeded: 181 days in Baia Mare, 190 days in Turulung Vii and 195 days in Şimleul Silvaniei (Tab.3).

In the experimental year 2013, the thermal balance with the highest values was recorded in Şimleul Silvaniei (the global thermal balance $(\Sigma \mathrm{tg})$ $3702^{\circ} \mathrm{C}$, the active thermal balance $\left(\Sigma\right.$ ta) $3329^{\circ} \mathrm{C}$ and the useful thermal balance $(\Sigma \mathrm{tu}) 1525^{\circ} \mathrm{C}$. Thus, in Şimleul Silvaniei and as well as in the other two

Tab.2. Absolute maximum, absolute minimum and average temperature of the air for the year 2013 in the three areas

\begin{tabular}{|c|c|c|c|c|c|c|c|c|c|c|c|c|c|c|}
\hline & \multirow[b]{2}{*}{ Area } & \multicolumn{12}{|c|}{ Months } & \multirow{2}{*}{$\begin{array}{c}\text { Max } \\
\text { Min } \\
\text { Average }\end{array}$} \\
\hline & & I & II & III & IV & V & VI & VII & VIII & IX & X & XI & XII & \\
\hline \multirow{3}{*}{$\sum_{\infty}^{*}$} & Max & 12.8 & 13.8 & 15.8 & 29.2 & 28.3 & 31.4 & 32.3 & 35.6 & 23.9 & 24.6 & 19.2 & 12.5 & 35.6 \\
\hline & Min & -13.2 & -10.6 & -11.6 & -2.5 & 6.3 & 5.1 & 8.6 & 6.7 & 0.3 & -3.6 & -6.5 & -11.6 & -13.2 \\
\hline & Average & -1.8 & 1.2 & 1.9 & 10.9 & 15.7 & 17.6 & 19.0 & 19.6 & 11.7 & 10.6 & 6.9 & -1.1 & 9.4 \\
\hline \multirow{3}{*}{$\begin{array}{l}\stackrel{*}{*} \\
\tilde{s} .\end{array}$} & Max & 10.4 & 14.9 & 17.1 & 28.0 & 29.9 & 32.7 & 34.6 & 37.2 & 25.7 & 21.6 & 18.4 & 11.0 & 37.2 \\
\hline & Min & -9.8 & -10.7 & -8.3 & 1.0 & 8.6 & 9.9 & 8.1 & 7.0 & 1.6 & -4.9 & -8.1 & -12.2 & -12.7 \\
\hline & Average & -2.1 & 2.9 & 5.8 & 11.4 & 18.2 & 21.1 & 22.0 & 19.7 & 16.2 & 10.4 & 8.9 & -2.0 & 11.0 \\
\hline \multirow{3}{*}{ 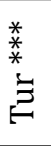 } & Max & 13.2 & 16.0 & 15.5 & 30.5 & 29.6 & 34.1 & 37.6 & 38.1 & 27.5 & 26.4 & 21.7 & 13.2 & 38.1 \\
\hline & Min & -10.1 & -5.8 & -9.9 & -0.2 & 7.3 & 8.7 & 8.3 & 7.3 & 0.8 & -5.1 & -7.0 & -8.9 & -10.1 \\
\hline & Average & -0.3 & 3.0 & 3.5 & 12.3 & 17.0 & 20.3 & 21.3 & 21.6 & 16.3 & 11.1 & 7.9 & 0.2 & 11.2 \\
\hline
\end{tabular}

*Baia Mare; **Şimleul Silvaniei; ${ }^{* * *}$ Turulung Vii

Tab.3. The main elements of the bioactive period of the air temperature in 2004-2012 and 2013 in the three areas

\begin{tabular}{|c|c|c|c|c|c|c|}
\hline \multirow{2}{*}{ Area } & \multirow{2}{*}{ Period } & \multicolumn{2}{|c|}{ Vegetation period } & \multicolumn{3}{|c|}{ Thermic balance } \\
\hline & & No. of days & Period & $\sum \operatorname{tg}^{*}$ & $\sum \mathrm{ta}^{* *}$ & $\sum \mathrm{tu}^{* * *}$ \\
\hline \multirow{2}{*}{ Baia Mare } & $\begin{array}{c}2004- \\
2012\end{array}$ & 171 & 03.IV - 21.IX & 2873 & 2816 & 1142 \\
\hline & 2013 & 181 & 01.IV - 28.IX & 2981 & 2928 & 1219 \\
\hline \multirow{2}{*}{ Şimleul Silvaniei } & $\begin{array}{c}2004- \\
2012\end{array}$ & 193 & 24.III - 03.X & 3699 & 3230 & 1510 \\
\hline & 2013 & 195 & 20.III - 01.X & 3702 & 3329 & 1525 \\
\hline \multirow{2}{*}{ Turulung Vii } & $\begin{array}{c}2004- \\
2012\end{array}$ & 181 & 01.IV - 27.IX & 2977 & 2901 & 1250 \\
\hline & 2013 & 190 & 25.III - 30.IX & 3697 & 3192 & 1455 \\
\hline
\end{tabular}

$* \sum \operatorname{tg}=$ Global thermal balance - summarizes all positive daily average temperatures during the active life

${ }^{* *} \sum \mathrm{ta}=$ Activ thermal balance - summarizes the temperatures above "biological zero" or reaches it.

${ }^{* * *} \sum \mathrm{tu}=$ Useful thermal balance - summarizes the differences of temperatures exceeding $10^{\circ} \mathrm{C}$ biological threshold 
areas, in 2013, temperatures above the average of the ten preceding years were recorded. These results confirm once again that 2013 was a very favorable year for the culture of vine (Tab. 3).

In other wine regions like Cozmeşti, from Huşi vineyard, during 2003-2007, the average overall heat balance was $3914.3^{\circ} \mathrm{C}$, the average of the active thermal balance was $3462.8^{\circ} \mathrm{C}$ and the useful thermal balance was $1469.3^{\circ} \mathrm{C}$ (Mursa, 2009). Also wine centers from Oltenia, where the active thermal balance oscillates between $3448^{\circ} \mathrm{C}$ in Segarcea, $3403^{\circ} \mathrm{C}$ in Banu Mărăcine, $3316^{\circ} \mathrm{C}$ in Drăgăşani (Popa et al., 2008; Dunoiu et al., 2008).

In Beltiug-Rătești center for viticulture which is part of the vineyard of Silvania, located in North-West of Romania, in 2009, the global thermal balance in the vegetation period was $(\Sigma \mathrm{tg})$ $3594.8^{\circ} \mathrm{C}$ and the active thermal balance was $(\Sigma \mathrm{ta})$ $3371.4^{\circ} \mathrm{C}$ also the useful thermal balance $(\Sigma \mathrm{tu})$ was $1855.1^{\circ} \mathrm{C}$. In 2010 , the global thermic balance in the vegetation period amounted to $(\Sigma \operatorname{tg}) 3476.1^{\circ} \mathrm{C}$ and useful thermal balance ( $\Sigma \mathrm{tu}$ ) was $1796.1^{\circ} \mathrm{C}$ (Hodor, 2011).

It was found that Simleul Silvaniei has the closest values to those mentioned above, being an area very favorable for vine growing. The amount of degrees of temperature within the other two areas show those two areas are favorable for vine growing.

Analyzing the precipitations during 20042012, the highest annual average was registered in Baia Mare (831.7 mm) (Tab. 4). But the other areas are also above the critical value of non-irrigated cultures of vine. During the growing season, the average amount of rainfall in 10 years, showed the highest values in Baia Mare (537.7 mm), in Turulung Vii $414.4 \mathrm{~mm}$ and Simleul Silvaniei 322.9 $\mathrm{mm}$. Comparing these values with the average rainfall recorded in the vegetation period in other vineyards like Vânju Mare (309 mm), Corcova (374 mm), Sâmbureşti (385 mm) (Popa et al., 2008), it can be seen that the water demand in vine is covered in all three areas.

Hodor (2011) afirmed that in Beltiug-Rătești area, average of precipitations during 20002009 values ware $717.4 \mathrm{~mm}$, and in the period 1901-1999, a value of $623.8 \mathrm{~mm}$. Average of precipitations during the vegetation period (01.IV30.IX) was $417.7 \mathrm{~mm}$ (2000-2009), and between 1901-1999 was $426.6 \mathrm{~mm}$.

Tab. 4 shows the months with most precipitations were May and July in Baia Mare, July and September in Şimleul Silvaniei, and June and July in Turulung Vii. In contrast, the months with the lowest precipitations in the studied areas were recorded in January and February in Baia Mare, in Şimleul Silvaniei January and November, and February and October in Turulung Vii.

Analyzing the data in Tab. 5, it can be concluded that the amount of precipitations in 2013, in all three areas, is less than the amount of precipitations during the period 2004-2012. The highest amounts of precipitations were recorded in Baia Mare $(857.5 \mathrm{~mm})$ and the lowest amount of precipitations was recorded in Şimleul Silvaniei. Also, precipitations during the growing season in 2013 are lower than the average precipitations in the years 2004-2012. Based on the observations, it can be concluded that 2013 was a year of low precipitations compared to the average of 20042012 in the three studied areas.

The coefficient of precipitations $(\mathrm{Cp})$ represents the ratio between the precipitations during the growing season $(\mathrm{mm})$ and number of days in the growing season.

The Tab. 6 shows that during 2004-2012 the coefficient of precipitations is higher than in 2013, except for the area of Baia Mare, where Cp 2013

Tab.4. The average and sum of monthly and annual precipitations (mm) of the three areas in 2004-2012

\begin{tabular}{|c|c|c|c|c|c|c|c|c|c|c|c|c|c|c|}
\hline \multirow{2}{*}{$\underset{\circlearrowright}{\mathbb{Z}}$} & \multicolumn{12}{|c|}{ Months } & \multirow{2}{*}{$\begin{array}{c}\sum \mathrm{pp} \\
\text { active }\end{array}$} & \multirow{2}{*}{$\underset{\text { annual }}{\sum \mathrm{pp}}$} \\
\hline & I & II & III & IV & $\mathrm{V}$ & VI & VII & VIII & IX & $\mathrm{X}$ & XI & XII & & \\
\hline $\mathrm{BM}^{*}$ & 44.5 & 40.9 & 54.1 & 56.4 & 105.5 & 90.2 & 125.5 & 97.7 & 62.3 & 56.1 & 48.4 & 50.0 & 537.7 & 831.7 \\
\hline ŞS** & 28.2 & 33.6 & 35.3 & 63.9 & 31.0 & 50.8 & 72.0 & 23.7 & 81.5 & 28.6 & 20.2 & 44.7 & 322.9 & 513.5 \\
\hline TUR*** & 44.2 & 40.4 & 42.2 & 50.1 & 70.0 & 80.9 & 87.1 & 76.2 & 50.1 & 41.3 & 46.6 & 58.0 & 414.4 & 687.1 \\
\hline
\end{tabular}

$\sum p p$ activ = precipitation in the active period (03.IV - 21.IX) at Baia Mare

$\sum$ pp activ = precipitation in the active period $(24 . I I I-03 . X)$ at Şimleul Silvaniei

$\sum$ pp activ $=$ precipitation in the active period at (01.IV - 27.IX) Turulung Vii

*Baia Mare; **Şimleul Silvaniei; ${ }^{* * *}$ Turulung Vii 
Tab. 5. The average and sun of monthly and annual precipitations ( $\mathrm{mm}$ ) of the three areas in 2013

\begin{tabular}{|c|c|c|c|c|c|c|c|c|c|c|c|c|c|c|}
\hline \multirow{2}{*}{ 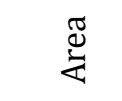 } & \multicolumn{12}{|c|}{ Months } & \multirow{2}{*}{$\underset{\text { active }}{\sum \mathrm{pp}}$} & \multirow{2}{*}{$\underset{\text { annual }}{\sum \mathrm{pp}}$} \\
\hline & I & II & III & IV & V & VI & VII & VIII & IX & $X$ & XI & XII & & \\
\hline $\mathrm{BM}^{*}$ & 36.0 & 33.6 & 128.8 & 75.9 & 121.2 & 141.6 & 52.2 & 129.0 & 56.4 & 29.2 & 43.0 & 10.6 & 576.3 & 857.5 \\
\hline ŞS** & 19.2 & 21.7 & 45.1 & 55.9 & 31.0 & 50.7 & 60.0 & 25.5 & 74.0 & 31.8 & 11.1 & 40.7 & 297,1 & 466.7 \\
\hline TUR*** & 55.5 & 35.0 & 180.9 & 49.9 & 63.3 & 118.5 & 8.9 & 30.8 & 67.6 & 27.6 & 28.9 & 7.0 & 345.0 & 679.9 \\
\hline
\end{tabular}

$\sum$ pp activ = precipitation in the active period (01.IV - 28.IX) at Baia Mare

$\sum$ pp activ $=$ precipitation in the active period (20.III - 01.X) at Şimleul Silvaniei

Spp activ = precipitation in the active period (25.III - 30.IX) at Turulung Vii

*Baia Mare; **Şimleul Silvaniei; ***Turulung Vii

Tab. 6. The coefficient of precipitations in the three areas analyzed

\begin{tabular}{lcc}
\hline Area & Cp 2004-2012 & Cp 2013 \\
\hline Baia Mare & 3.11 & 3.18 \\
Şimleul Silvaniei & 1.67 & 1.52 \\
Turulung Vii & 2.28 & 1.81 \\
\hline
\end{tabular}

$\mathrm{Cp}=$ precipitation coefficient

Tab. 7. Qualitative characteristics of the tested varieties in three different areas from NW Romania, 2013

\begin{tabular}{cccccc}
\hline Variety & Area & $\begin{array}{c}\text { Sugar } \\
(\mathrm{g} / \mathrm{L})\end{array}$ & $\begin{array}{c}\text { Acidity } \\
\left(\mathrm{g}^{2} / \mathrm{L} \mathrm{H}_{2} \mathrm{SO}_{4}\right)\end{array}$ & $\begin{array}{c}\text { Weight of } 100 \\
\text { berries }(\mathrm{g})\end{array}$ & $\mathrm{pH}$ \\
\hline Feteasca albă & Baia Mare & $171 \pm 1.63^{\mathrm{g}}$ & $5.09 \pm 0.16^{\text {cde }}$ & $154.98 \pm 3.51^{\mathrm{c}}$ & $3.13 \pm 0.12^{\mathrm{bc}}$ \\
& Şimleul Silvaniei & $203 \pm 1.52^{\mathrm{a}}$ & $4.83 \pm 0.13^{\text {ef }}$ & $129.77 \pm 2.65^{\mathrm{e}}$ & $3.08 \pm 0.21^{\mathrm{c}}$ \\
& Turulung & $198 \pm 3.21^{\mathrm{c}}$ & $5.08 \pm 0.23^{\mathrm{de}}$ & $138.50 \pm 6.03^{\mathrm{d}}$ & $3.18 \pm 0.13^{\mathrm{bc}}$ \\
\hline Feteasca regală & Baia Mare & $166 \pm 2.08^{\mathrm{h}}$ & $6.48 \pm 0.55^{\mathrm{a}}$ & $190.63 \pm 6.11^{\mathrm{a}}$ & $2.86 \pm 0.18^{\mathrm{d}}$ \\
& Şmleul Silvaniei & $184 \pm 3.05^{\mathrm{e}}$ & $5.32 \pm 0.29^{\mathrm{cd}}$ & $182.77 \pm 9.45^{\mathrm{b}}$ & $3.12 \pm 0.29^{\mathrm{bc}}$ \\
& Turulung & $183 \pm 2.00^{\mathrm{e}}$ & $6.11 \pm 0.56^{\mathrm{b}}$ & $189.27 \pm 8.50^{\mathrm{a}}$ & $3.06 \pm 0.09^{\mathrm{c}}$ \\
\hline Riesling italian & Baia Mare & $174 \pm 0.57^{\mathrm{f}}$ & $5.38 \pm 0.15^{\mathrm{c}}$ & $121.24 \pm 4.04^{\mathrm{f}}$ & $3.43 \pm 0.26^{\mathrm{a}}$ \\
& Şimleul Silvaniei & $201 \pm 3.03^{\mathrm{b}}$ & $4.72 \pm 0.32^{\mathrm{f}}$ & $131.87 \pm 7.00^{\mathrm{e}}$ & $3.23 \pm 0.23^{\mathrm{b}}$ \\
& Turulung & $193 \pm 3.60^{\mathrm{d}}$ & $4.82 \pm 0.26^{\text {ef }}$ & $127.79 \pm 3.61^{\mathrm{e}}$ & $3.20 \pm 0.12^{\mathrm{bc}}$ \\
& LSD 0.05 $=$ & $1.86-2.04$ & $0.30-0.33$ & $5.29-5.81$ & $0.13-0.15$ \\
\hline
\end{tabular}

Average value $\pm S D(n=3)$; in each column, mean values with different letters are significantly different at $\mathrm{P}<0.05$

(3.18) is higher than Cp 2004-2012 (3.11), the values are slightly lower than the stability limit for vines in Şimleul Silvaniei (1.7), which expresses deficit in precipitations, but it is favorable for quality.

\section{Analysis of the main qualitative indicators of the studied varieties}

In all three varieties taken into study in the areas of culture, the differences between the variants as regarding the sugar content, acidity, mass of 100 grapes, $\mathrm{pH}$ are statistically covered. The highest quantity of sugar was accumulated by 'Feteasca albă' cultivated in Şimleul Silvaniei (203 g/L), followed by 'Riesling italian' with a significant difference in Şimleul Silvaniei $(201 \mathrm{~g} / \mathrm{L})$ (Tab. 7). The results of the other varieties are quite different, especially 'Fetească regală' cultivated in Baia Mare has accumulated $166 \mathrm{~g} / \mathrm{L}$ sugar. These results are lower than those shown by Bunea 
(2010) $171 \mathrm{~g} / \mathrm{L}$ in Gherla, Lung et al., 2012 in ClujNapoca, 183 g/L, but higher than those obtained by Damian and Calistru (1992), $154 \mathrm{~g} / \mathrm{L}$ in Iaşi.

The highest acidity was recorded in 'Fetească regală' $\left(6.48 \mathrm{~g} / \mathrm{L} \mathrm{H}_{2} \mathrm{SO}_{4}\right)$ in all studied areas of culture (Tab. 7). The result is very good, the value is higher than that obtained in Dealu Bujorului 5.3 g/ $\mathrm{L} \mathrm{H}_{2} \mathrm{SO}_{4}$ by Simon (1998) and Moldovan (1998) in Blaj $\left(6.2 \mathrm{~g} / \mathrm{L} \mathrm{H}_{2} \mathrm{SO}_{4}\right)$. The lowest acidity was registered in 'Riesling italian' in Şimleul Silvaniei ( $4.72 \mathrm{~g} / \mathrm{L} \mathrm{H}_{2} \mathrm{SO}_{4}$ ).

The values of acidity are in the normal limit specific for the grown varieties. The weight of 100 grapes was highest for 'Fetească regală' (182.7$190.6 \mathrm{~g}$ ) in all studied areas. The highest $\mathrm{pH}$ was 3.43 in 'Riesling italian' from Baia Mare and the lowest was 2.86 in 'Fetească regală' in the same area. In the case of $\mathrm{pH}$, the other experimental variants are virtually equal in statistical terms. Although ecoclimatic conditions particularly affect the quality of production, the soil is essential for the production, but may have influence also on the quality, due to its chemical composition. The soil acidity and $\mathrm{pH}$ affect the varieties, thus, lower values of these can be noted in Simleul Silvaniei, compared to Baia Mare or Turulung Vii.

\section{CONCLUSIONS}

The type of soil in Baia Mare is aluvosoil, in Şimleul Silvaniei luvosoil and in Turulung Vii preluvosoil, which are all suitable for cultivating vines.

In the area of Baia Mare, the daily average temperature in the last century was $8.6^{\circ} \mathrm{C}$, an absolute maximum of $35.8^{\circ} \mathrm{C}$, an absolute minimum of $-21.7^{\circ} \mathrm{C}$. In 2013 , the average daily temperature was $9.4^{\circ} \mathrm{C}$ and had a total of 181 days with temperatures in the active period. In Şimleul Silvaniei the average daily temperature in the last decade was $12.2^{\circ} \mathrm{C}$, an absolute maximum of $39.7^{\circ} \mathrm{C}$ and an absolute minimum of $-23.2^{\circ} \mathrm{C}$. In 2013 the average daily temperature was $11.0^{\circ} \mathrm{C}$ and 195 days in the active period. Turulung Vii had a daily average temperature of $10.3^{\circ} \mathrm{C}$ in the last decade. In 2013 , the average daily temperature was $11.2^{\circ} \mathrm{C}$ with a number of 190 days during the growing season.

In terms of precipitations concerning the year 2013 , the amount of precipitations was lower than the average of the years 2004-2012 in the three areas studied.
Regarding the amount of sugar accumulated, 'Fetească albă' from Şimleul Silvaniei recorded the highest values (203 g/L) followed by 'Riesling italian' grown in the same area, with a significant difference $(201 \mathrm{~g} / \mathrm{L})$. In contrast, 'Fetească regală' from Baia Mare recorded the lowest values (166 $\mathrm{g} / \mathrm{L}$ ) in sugar. The highest acidity was recorded in 'Fetească regală' $\left(6.48 \mathrm{~g} / \mathrm{L} \mathrm{H}_{2} \mathrm{SO}_{4}\right)$ in all areas of culture and the lowest amount of acidity was registered in 'Riesling italian' in Şimleul Silvaniei ( $4.72 \mathrm{~g} / \mathrm{L} \mathrm{H}_{2} \mathrm{SO}_{4}$ ). The weight of 100 grapes had the highest values for 'Fetească regală' (182.7-190.6 g) in all studied areas. The highest value in $\mathrm{pH}$ was achieved in 'Riesling italian' from Baia Mare, and the lowest in 'Fetească regală' in the same area.

Research results indicate a good suitability of the three varieties tested for cultivation in the conditions from north-western Romania, in order to obtain a high quality wine, except the area of Baia Mare, which in some years can only get current table wines.

Acknowledgements. This paper was published under the frame of European Social Fund, Human Resources Development Operational Programme 2007-2013, projectno. POSDRU/159/1.5/S/132765.

\section{REFERENCES}

1. Blaga G, Filipov F, Udrescu S, Rusu I, Vasile D (2005). Pedology. Ed. AcademicPres. Cluj-Napoca.

2. Bunea CI, Marin A, Pop N, Bunea A, Babeș A, Calugăr A (2010). Influence of Variety and Type of Cultivation (Organic and Conventional) on Quality, in Five Wine Grape Varieties, Grown in Cluj Country, Romania. Bulletin UASVM Horticulture 67(1):179-182.

3. Bunea CI (2010). Studies on variability of main productivity and quality characters in a collection of wine varieties concerning their suitability to organic culture technologies and marketing. PhD thesis. UASVM. ClujNapoca.

4. Bunea CI, Popesc D, Bunea A, Ardelean M (2013). Variation of attack degree of downy mildew (Plasmopara viticola) in five wine grape varieties, under conventional and organic control treatments. Journal of Food, Agriculture \& Environment 11(3-4):1166-1170.

5. Călugar A, Pop N, Farago M, Babeș A, Hodor D, Bunea CI (2009). Influence of Critical Environmental Factors on Elements of Fertility at Grape Varieties Created at S.C.D.V.V. Blaj. Bulletin UASVM Horticulture 66(1):255-259.

6. Damian D, Calistru G (1992). Possibility of enlarging Iași varietal conveyor with table grape varieties. Magazine Agricultural Research in Moldova.

7. Damian F, Damian G, Lăcătușu R, Macovei G, Iepure G, Năprădean I, Chira R, Kollar L, Rață L, Zaharia DC (2008). 
Soils from the Baia Mare Zone and the Heavy Metals Pollution. Carpth. J. of Earth and Environmental Sciences 3(1):85-98.

8. Dobrei A, Sala F, Victoria M (2009). Local Grapes Biotypes and Varietis - a Source for Biodiversity, Specificity and Authenticity. Bulletin UASVM Horticulture, 66(1): 260266.

9. Dunoiu A, Popa A, Dicu C, Onescu C (2008). Factors that decide the vocation for obtaining high quality red wines, having controlled origin denomination in Oltenia. UASMV Horticulture, 65(1):362-368.

10. Gladstones J (1992). Viticulture and environment. Winetitles. Adelaide.

11. Hodor DM (2011). Suitability of some grape varieties used for obtaining superior quality red wines, cultivated in North-West region of Romania. PhD thesis. USAMV. ClujNapoca.

12. Lung ML, Pop N, Ciobanu F, Babeș A, Bunea CI, Lazar S (2012). Environmental Factors Influence on Quality of Wine Grape Varieties in Four Different Areas of Culture. Bulletin UASMV Horticulture, 69(1):219-227.

13. Moldovan SD (1998). Contribution to creating resistant varieties vine vineyards from Transylvania. $\mathrm{PhD}$ thesis. UASVM. Iași.

14. Mursa D (2009). Behavior of vine varieties for red wines grafted on different rootstocks as the center of vineyard wine Cozmești Huși. PhD thesis. USAMV. Iași.
15. Pop N (2010). Course general viticulture. Ed. Eikon. ClujNapoca.

16. Popa A, Dunoiu A, Genoiu C, Onescu J (2008). The obtaining of high quality wines having Controlled Origin Denomination within Dealul Olt-Dragasani area. Bulletin UASVM-CN 65(1-2):356-361.

17. Schaller K (2011). Quality of Grapevines - Endogenous and Exogenous Factors and Their Differing Influences. Bulletin UASVM Horticulture, 68(1): 177-184.

18. Seguin G (1986). "Terroirs" and pedology of vinegrowing. Experientia 42:861-873.

19. Simion C (1998). Ecosystem study Vinifera varietes rootstocks to determine the most appropriate rootstock vineyard hills Bujorului (country. Galați). PhD thesis. UASVM. Iași.

20. Szentesi Al (2002). Contributions to the study of relevant agrochemical indices of soil in north-west of our country. PhD thesis. UASVM. Cluj-Napoca.

21. Teodorescu CS, Popa AI, Gheorghe SN (1987). Romania Oenoclimat (Romania and climate wines their characteristic). Ed. Științifică și Enciclopedică București.

22. Winkler A, Cook J, Kliewer W, Lider L (1974). General viticulture. University of California press. Berkeley. 